\title{
Poles Permukaan AISI 316 L dengan Metode Drag Finishing
}

\author{
I. P. Sayuti1,* dan Suyitno ${ }^{2}$ \\ 'Departemen Teknik Mesin dan Industri Fakultas Teknik Universitas Gadjah Mada \\ Yogyakarta 55281, Indonesia \\ Telp. (0274) 521673 \\ ${ }^{2}$ Center for Innovation of Medical Equipment and Devices (CIMEDs), Fakultas Teknik, Universitas Gadjah Mada, \\ Yogyakarta 55281, Indonesia \\ Telp. (0274) 521673 \\ *e-mail: ilhamperdanasayuti@gmail.com
}

\begin{abstract}
Articial knee joint is a prosthesis placed inside human body which need a proper surface roughness level to minimize wear due to frictions. One of the best method to reduce material surface roughness level is using drag finishing method. This study aims to determine the effects of spindle rotational speed and finishing duration on drag finishing in terms of surface roughness level of specimens. Drag finishing process was carried out with abrasive media of acrylic. The study was conducted on stainless steel AISI 316 L specimens which is the material for making femoral component of artificial knee joint. Geometry of specimens were conditioned as small cylinder with length of $35 \mathrm{~mm}$ and diameter of $10 \mathrm{~mm}$. The initial roughness $\mathrm{R}_{a}$ for specimen was 0,65 um. Drag finishing result showed that the best parameter for drag finishing using acrilic are $160 \mathrm{rpm}$ and 15 minutes which produced a roughness level $\mathrm{R}_{a}$ of $0,47 \mu \mathrm{m}$.
\end{abstract}

Keywords: Artificial knee joints, drag finishing, surface roughness.

\begin{abstract}
Abstrak
Sendi lutut artifisial sebagai salah satu prostesis yang ditempatkan di dalam tubuh memerlukan tingkat kekasaran permukaan tertentu untuk meminimalisasi terjadinya keausan antar komponennya. Salah satu upaya untuk menurunkan tingkat kekasaran permukaan pada material dapat ditempuh dengan menggunakan metode drag finishing. Penelitian ini bertujuan untuk mengetahui pengaruh kecepatan putar spindle dan durasi pada proses drag finishing terhadap tingkat kekasaran permukaan spesimen uji berbentuk silinder berukuran panjang $35 \mathrm{~mm}$ dengan diameter $10 \mathrm{~mm}$. Spesimen uji dibuat dari material AISI $316 \mathrm{~L}$ yang menjadi salah satu material pembuatan sendi lutut artifisial. Jenis media abrasif yang digunakan adalah plastik jenis akrilik dengan profil bola berdiameter $4 \mathrm{~mm}$. Proses drag finishing yang dilakukan menunjukkan bahwa kecepatan putar spindle dan durasi finishing yang ideal untuk proses drag finishing adalah 160 rpm selama 15 menit dan menghasilkan kekasaran permukaan sebesar 0,471 $\mu \mathrm{mRa}$.
\end{abstract}

Kata kunci: sendi lutut artifisial, drag finishing, kekasaran permukaan. 


\section{PENDAHULUAN}

Penggunaan lutut artifisial dalam proses pembedahan yang disebut Total Knee Arthroplasty terus berkembang menjadi lebih baik (Long dan Rack, 1998). Evolusi desain terus terjadi dimulai dari desain awal yang sederhana hingga desain modern yang memperhitungkan segala macam pembebanan dan interaksi antar komponen yang kompleks. Dikarenakan lutut artifisial ini diimplantasikan ke dalam tubuh dan saling berinteraksi dengan material, lutut artifisial harus mampu berfungsi dengan baik dengan mencegah keausan (Nine dkk, 2014). Penelitian berbagai jenis material biokompatibel pada lutut artifisial dilakukan untuk mengetahui ketahanannya terhadap keausan (Long dan Rack, 1998).

Meskipun lutut artifisial ini telah cukup baik dalam menangani keluhan osteoarthiritis lutut pada banyak kasus, namun resiko kegagalan pada lutut artifisial tetaplah ada. Kegagalan pada lutut artifisial biasanya disebabkan oleh pengenduran aseptik (aseptic loosening), infeksi, dan keausan polyethylene insert (Jaber dkk, 2015). Salah satu penyebab utama terjadinya keausan ini adalah bagian permukaan logam yang tidak cukup halus (Jaber dkk, 2015). Permukaan logam dari komponen femoral yang mekanisme geraknya mengalami kontak dengan polyethylene insert menyebabkan terjadinya gesekan antara kedua komponen. Kurang halusnya permukaan komponen femoral meningkatkan keausan pada polyethylene hingga tiga kali lipat (Muratoglu $\mathrm{dkk}, 2004)$.

Untuk menciptakan lutut artifisial yang baik, permukaan komponennya juga harus halus sehingga dapat meminimalisasi adanya tegangan kontak yang tersisa di sana (Chowdury dkk, 2004). Proses penghalusan permukaan komponen pada lutut artifisial dapat menggunakan mesin kategori deburring dan finishing (Barletta dkk., 2014).

Sebagai faktor penentu kualitas permukaan, kekasaran permukaan menentukan karakteristik geometri dan performa fisik dan mekanis dari sebuah benda, terutama pada laju keausan yang dapat terjadi. Keausan sangat dipengaruhi oleh kekasaran permukaan awal dari dua benda yang bergesekan. Dengan meningkatnya pembebanan pada kontak antara dua permukaan, laju keausan pada benda dengan kekasaran yang besar menjadi semakin meningkat. Untuk memperhalus permukaan komponen maka diperlukan proses finishing yang tepat.

Drag finishing merupakan salah satu proses penghalusan permukaan yang digunakan pada peralatan medis seperti pada lutut artifisial (Barletta dkk., 2014). Penggunaan metode drag finishing tergolong efisien karena mampu melakukan finishing pada sejumlah benda kerja tanpa adanya benturan antar benda yang akan dilakukan finishing membuat metode ini cocok digunakan pada sendi lutut buatan (Barletta dkk., 2014). Konsep drag finishing yang memutar benda kerja untuk melakukan proses abrasi menyentuh media abrasif akan mampu menghilangkan partikelpartikel kasar bekas permesinan yang berada di ujung permukaan benda kerja sehingga kehalusan permukaan dapat ditingkatkan (Gillespie, 2007). Biaya pembelian ataupun pembuatan mesin drag finishing cukup mahal sehingga untuk penelitian ini dilakukan modifikasi mesin milling yang ada di laboratorium untuk dijadikan sebagai mesin drag finishing dengan memodifikasi spindle pemutarnya.

Proses drag finishing pada penelitian ini mencakup modifikasi alat, pembuatan media abrasif, dan pengamatan terhadap parameter-parameter yang mempengaruhi kehalusan permukaan hasil drag finishing. Penelitian ini bertujuan untuk mengetahui pengaruh parameter kecepatan putar spindle dan durasi finishing terhadap kekasaran permukaan spesimen uji. Diharapkan penelitian ini mampu mewujudkan pengerjaan drag finishing yang sederhana dan efisien untuk menghasilkan prostesis berkualitas yang mampu menjawab kebutuhan industri kesehatan di Indonesia. 


\section{METODE PENELITIAN}

Proses drag finishing memerlukan adanya spindle yang berfungsi sebagai holder untuk melekatkan benda uji ke motor penggerak berupa mesin milling. Spindle ini dibuat dari material baja dengan melewati proses bubut, milling, dan pengelasan. Dikarenakan spindle akan dipasangkan di mesin milling maka ukuran spindle harus menyesuaikan space yang terdapat pada mesin milling yaitu antara meja milling dan motor penggerak mesin, juga mempertimbangkan ukuran wadah dan media abrasif yang akan diletakkan di meja milling.

Proses penghalusan pada drag finishing menggunakan media abrasif. Salah satu media abrasif untuk mass finishing yang paling umum digunakan adalah media dari bahan plastik (Holzknecht, 2009). Media tersebut memiliki kehandalan dalam proses deburring, ball burnishing, drying, dan dry polishing. Jenis media abrasif yang digunakan pada penelitian ini adalah material plastik jenis akrilik berbentuk bola dengan diameter $4 \mathrm{~mm}$. Media abrasif ini kemudian ditempatkan ke dalam wadah alumunium berdiameter $36 \mathrm{~cm}$. Jumlah media abrasif yang digunakan yaitu sejumlah $5 \mathrm{~kg}$.

Hal lain yang perlu untuk dipersiapkan sebelum pengujian adalah spesimen uji. Penggunaan spesimen uji dimaksudkan untuk memperoleh parameter ideal pada proses drag finishing dengan media abrasif akrilik. Parameter ideal ini kemudian dapat diaplikasikan pada komponen femoral sendi lutut artifisial yang akan dilakukan proses drag finishing pada penelitian selanjutnya.

Material yang digunakan sebagai spesimen uji pada penelitian ini adalah AISI 316 L. Pemilihan material ini menyesuaikan pada material yang digunakan pada sendi lutut artifisial. AISI 316 L merupakan material biocompatible yang memiliki kombinasi sifat mekanis yang baik seperti kekerasan, keuletan, ketahanan, dan kekuatan. AISI 316 L juga memiliki ketahanan korosi yang baik dikarenakan adanya lapisan pasif oksida yang terbentuk pada permukaan logam (Nine dkk, 2014).

Material spesimen uji yang didapatkan berupa silinder AISI 316 L sepanjang $35 \mathrm{~mm}$ dengan diameter $10 \mathrm{~mm}$.

Selanjutnya dilakukan proses pembubutan muka untuk memakan permukaan spesimen sehingga didapatkan keseragaman ukuran kekasaran permukaan awal spesimen uji. Proses ini menggunakan mesin CNC bubut dengan pemakanan sedalam 0,2 $\mathrm{mm}$

Kemudian dilakukan pengukuran kekasaran permukaan awal spesimen uji hasil pembubutan muka dengan menggunakan alat ukur kekasaran permukaan stylus profilometer

Setelah spindle, media abrasif, serta spesimen uji tersedia, maka proses drag finishing siap untuk dilakukan. Assembly dari komponen-komponen drag finishing pada penelitian ini dapat dilihat pada Gambar 1. 


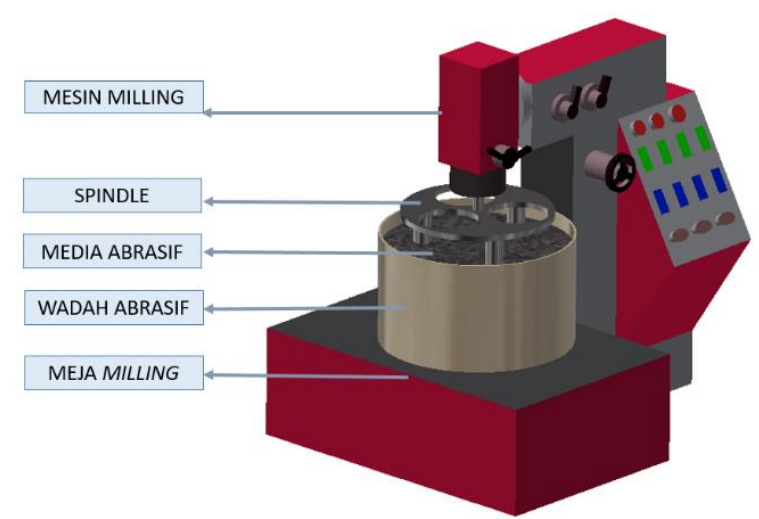

Gambar 1. Susunan alat pada proses drag finishing di Mesin Milling

Proses drag finishing dilakukan dengan melekatkan spesimen uji pada spindle lalu dipasangkan pada mesin milling. Spindle yang berputar tersebut dimasukkan pada wadah berisi media abrasif akrilik. Proses ini pertama kali dilakukan terhadap variasi kecepatan putar spindle. Variasi kecepatan putar spindle yang digunakan menyesuaikan kecepatan putar yang ada pada mesin milling yaitu 80, 160, 245, 360, dan $490 \mathrm{rpm}$. Ada tiga buah spesimen yang diujikan pada tiap variasi rpm dengan tujuan untuk mengetahui konsistensi hasil finishing. Masing-masing rpm tersebut diujikan dengan nilai durasi finishing yang berbeda dengan menyamakan jumlah siklus putaran spindle. Oleh karena itu nilai durasi setiap kecepatan putar spindle ditentukan dengan menggunakan rumus berikut.

$$
\text { Durasi }=\frac{\text { jumlah putaran }}{\text { kecepatan putar spindle }}
$$

Formula tersebut menjadi dasar untuk mendapatkan durasi pengujian yang seimbang untuk setiap kecepatan putar spindle. Contohnya dengan menggunakan penyamaan siklus menjadi 1000 putaran, maka untuk proses drag finishing dengan kecepatan putar spindle 80 RPM maka ditentukan durasi pengujian selama 12,5 menit. Begitu juga dengan kecepatan putar spindle 490 RPM yang menggunakan waktu finishing selama 2,04 menit.

Hasil proses drag finishing dengan parameter kecepatan putar spindle kemudian diukur kekasaran permukaannya menggunakan alat ukur kekasaran permukaan stylus profilometer. Kemudian dibandingkan masing-masing nilai kekasaran permukaan lalu diambil kekasaran permukaan yang terendah. Untuk memudahkan analisis data maka hasil pengukuran dibuat dalam bentuk grafik.

Setelah didapatkan nilai kecepatan putar spindle terbaik yang menghasilkan kekasaran permukaan yang terendah lalu kecepatan ini digunakan untuk pengujian selanjutnya terhadap variasi durasi finishing. Durasi yang digunakan adalah 5, 10, 15, 20, dan 25 menit. Ada tiga buah spesimen yang diujikan pada tiap variasi durasinya dengan tujuan untuk mengetahui konsistensi hasil finishing. Proses ini dilakukan menggunakan mesin milling.

Hasil proses drag finishing diukur kekasaran permukaannya menggunakan alat ukur kekasaran permukaan stylus profilometer. Kemudian dibandingkan masing-masing nilai kekasaran permukaan lalu diambil kekasaran permukaan yang terendah. Untuk memudahkan analisis data maka hasil pengukuran dibuat dalam bentuk grafik. 


\section{HASIL DAN PEMBAHASAN}

Hasil drag finishing ditunjukkan pada Gambar 2. Gambar 2 menunjukkan terjadinya perubahan kekasaran permukaan pada tiap perlakuan drag finishing dengan variasi kecepatan. Kekasaran awal permukaan $\mathrm{R}_{\mathrm{a}}$ sebesar $0,65 \mu \mathrm{m}$ mengalami penurunan kekasaran pada drag finishing dengan kecepatan $80 \mathrm{rpm}$ menjadi 0,60 $\mu \mathrm{m}$. Nilai kekasaran permukaan kembali mengalami penurunan pada kecepatan $160 \mathrm{rpm}$ menjadi $0,56 \mu \mathrm{m}$. Kemudian nilai kekasaran hampir tidak mengalami perubahan pada $245 \mathrm{rpm}$ yaitu kekasaran 0,56 $\mu \mathrm{m}$. Kekasaran permukaan $\mathrm{R}_{\mathrm{a}}$ kemudian justru mengalami peningkatan pada rpm setelahnya yaitu 360 dan 490 rpm dengan nilai kekasaran 0,58 dan 0,62 $\mu \mathrm{m}$. Namun keseluruhan nilai kekasaran berdasarkan variasi kecepatan spindle tetap berada di bawah nilai kekasaran awal.

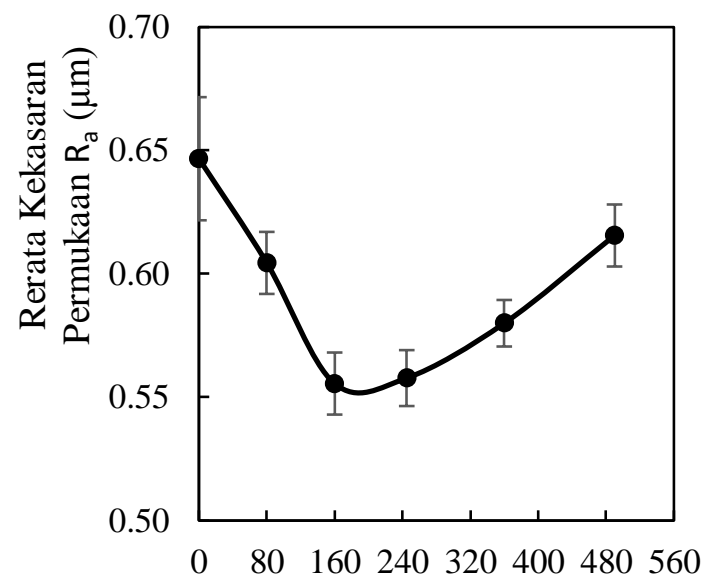

\section{Kecepatan (rpm) \\ Gambar 2. Grafik kekasaran permukaan hasil drag finishing terhadap kecepatan spindle}

Perubahan kekasaran permukaan uji juga ditunjukkan oleh morfologi permukaan spesimen uji pada Gambar 3. Pada spesimen uji awal (pra-finishing) terlihat garis-garis hasil permesinan dengan mesin bubut. Terjadinya proses drag finishing dengan media plastik akrilik menyebabkan garis-garis itu menjadi samar dan memunculkan titik-titik hasil pemakanan spesimen oleh media abrasif. Pada kecepatan 80 hingga $245 \mathrm{rpm}$, morfologi spesimen tampak memiliki titik hasil finishing yang merata. Terlihat pada Gambar 3(b) garis hasil permesinan mulai samar jika dibandingkan dengan morfologi sebelum finishing (Gambar 3(a)) dan mengalami penurunan kekasaran $\mathrm{R}_{\mathrm{a}}$ dari 0,65 menjadi 0,60 $\mu \mathrm{m}$. Pada kecepatan 160 dan $245 \mathrm{rpm}$ kembali terlihat bahwa garis semakin samar yaitu dengan kekasaran permukaan $\mathrm{R}_{\mathrm{a}} 0,56 \mu \mathrm{m}$. Sedangkan pada kecepatan 360 dan $490 \mathrm{rpm}$ ceruk hasil finishing kurang merata persebarannya sehingga saat diukur nilai kekasaran menjadi lebih tinggi daripada kecepatan 80 sampai $245 \mathrm{rpm}$. Bahkan morfologi pada kecepatan $490 \mathrm{rpm}$ (Gambar 3(f)) menunjukkan adanya crater (lingkaran putih) meskipun kekasaran yang dihasilkan yaitu 0,62 $\mu \mathrm{m}$ masih di bawah kekasaran awal 0,65 $\mu \mathrm{m}$.

Pengamatan pada proses drag finishing juga menunjukkan bahwa penyebab terjadinya peningkatan kekasaran tersebut dikarenakan kecepatan putar spindle yang terlalu tinggi menyebabkan banyak media abrasif akrilik yang terpental ke atas saat menabrak spesimen uji sehingga besar gaya kontak dan tekanan yang terjadi pada spesimen uji menurun dan 
mengakibatkan proses finishing menjadi tidak maksimal. Pada Kecepatan 80 dan 160 rpm, media abrasif tetap berada dalam wadah. Dimulai pada kecepatan spindle $245 \mathrm{rpm}$, media abrasif akrilik mulai terpental keluar. Dengan meningkatkan kecepatan pada 360 dan $490 \mathrm{rpm}$, jumlah media abrasif yang terpental keluar dari wadah menjadi semakin banyak sehingga diperlukan penutup bagi wadah media abrasif. Matsunaga dan Kobayashi (1981) menyatakan diperlukan adanya batasan kecepatan untuk mencegah terlontarnya media abrasif dari wadah yang menyebabkan proses finishing menjadi tidak efektif. Proses dragfinishing pada kecepatan spindle yang tinggi (245, 360, dan $490 \mathrm{rpm}$ ) memang dilanjutkan dengan menggunakan penutup media abrasif. Namun dengan mengambil fakta tersebut dapat disimpulkan proses drag finishing tidak lagi berlangsung secara maksimal pada kecepatan tersebut.

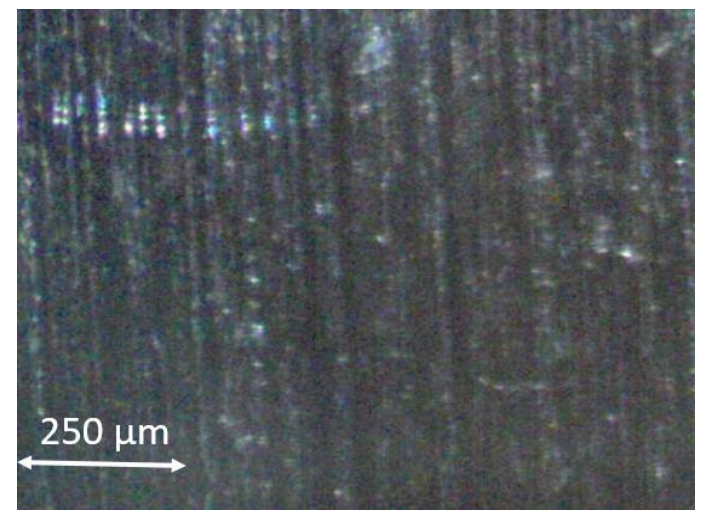

(a)

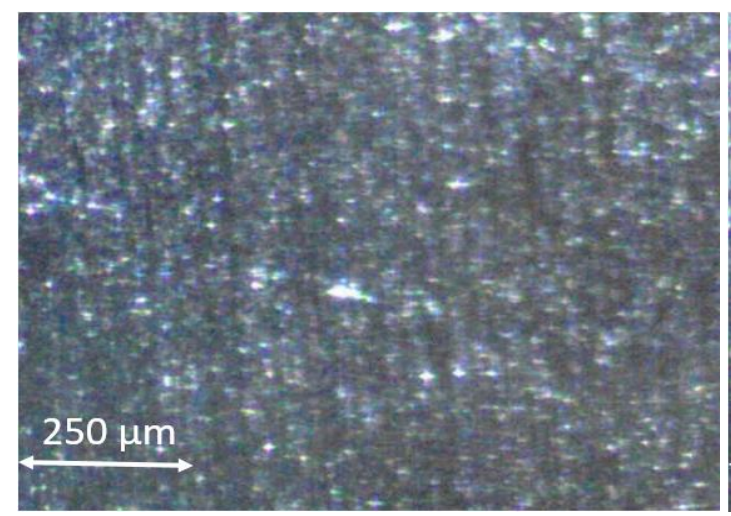

(c)

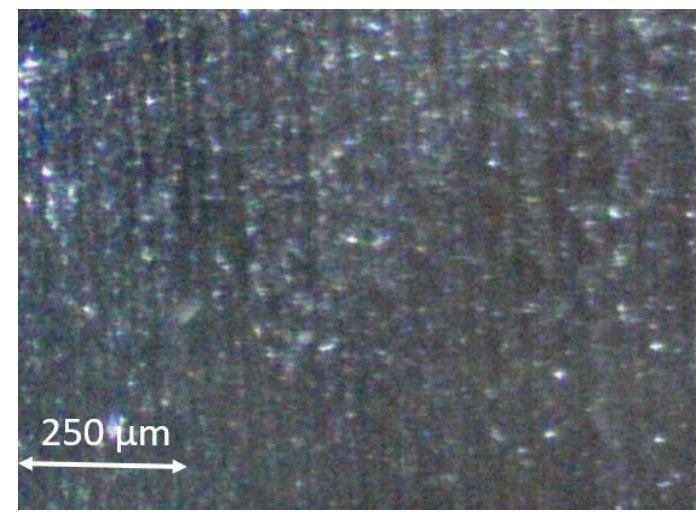

(b)

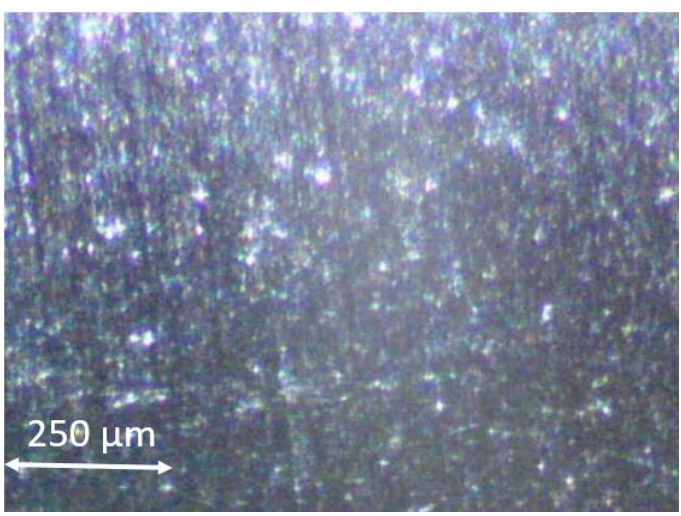

(d) 


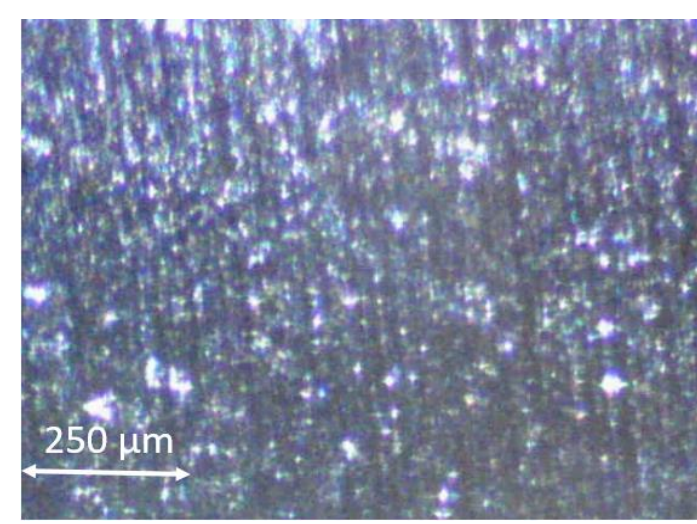

(e)

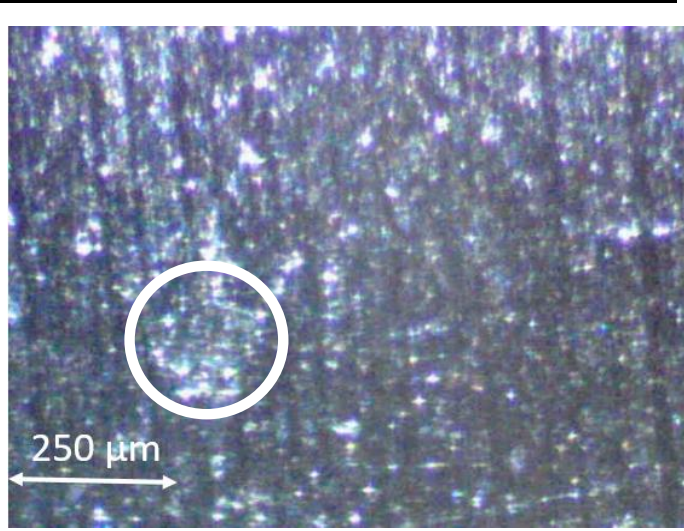

(f)

Gambar 3. Morfologi permukaan spesimen terhadap kecepatan putar spindle, (a) pra finishing, (b) $80 \mathrm{rpm}$, (c) $160 \mathrm{rpm},(d) 245 \mathrm{rpm},(\mathrm{e}) 360 \mathrm{rpm}$, (f) $490 \mathrm{rpm}$

Proses drag finishing dengan variasi kecepatan spindle menghasilkan perubahan massa spesimen uji seperti yang ditunjukkan pada Gambar 4. Grafik tersebut mempertegas pemaparan tentang tidak maksimalnya proses finishing pada kecepatan spindle 360 dan $490 \mathrm{rpm}$. Massa yang hilang meningkat hingga 0,013 g pada kecepatan $160 \mathrm{rpm}$ lalu kemudian mengalami penurunan mulai dari kecepatan $245 \mathrm{rpm}$.

Perlakuan drag finishing dengan variasi kecepatan spindle kemudian dihentikan karena data dan grafik dianggap telah cukup untuk merepresentasikan pengaruh kecepatan spindle terhadap nilai kekasaran permukaan spesimen uji. Dengan data-data yang ada maka diambil parameter kecepatan yang menghasilkan kekasaran permukaan terendah yaitu pada kecepatan spindle 160 rpm dengan kekasaran permukaan $\mathrm{R}_{\mathrm{a}} 0,56 \mu \mathrm{m}$.

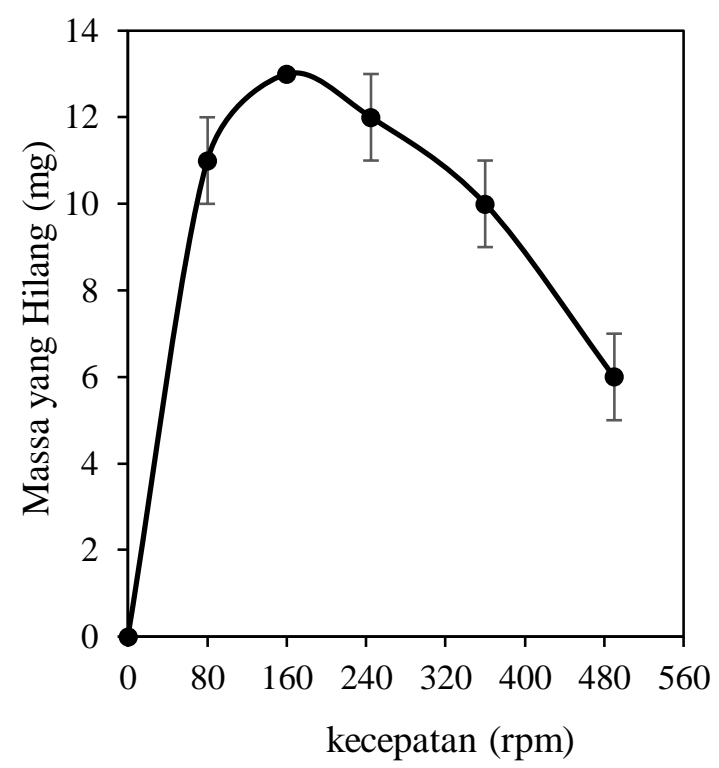

Gambar 4. Grafik perubahan massa spesimen uji pada drag finishing dengan variasi kecepatan spindle 
Perlakuan drag finishing dilanjutkan dengan menguji pengaruh durasi finishing terhadap kekasaran permukaan spesimen uji menggunakan nilai kecepatan spindle yang telah didapatkan sebelumnya. Hasil perlakuan tersebut ditunjukkan pada Gambar 5.

Grafik pada Gambar 5 menunjukkan bahwa kekasaran permukaan cenderung mengalami penurunan dengan bertambahnya durasi finishing. Kekasaran permukaan $\mathrm{R}_{\mathrm{a}}$ spesimen uji menurun dari $0,65 \mu \mathrm{m}$ menjadi $0,55 \mu \mathrm{m}$ durasi 5 menit, kemudian cenderung stabil pada durasi 10 menit yaitu $0,54 \mu \mathrm{m}$. Kekasaran permukaan kemudian menurun menjadi $0,47 \mu \mathrm{m}$ pada durasi 15 menit. Kemudian kekasaran permukaan sedikit mengalami kenaikan pada durasi 20 menit mencapai kekasaran 0,50 $\mu \mathrm{m}$. Saat dilanjutkan kembali kembali lagi pada durasi 25 menit kekasaran kembali turun menjadi $0,48 \mu \mathrm{m}$ yang tidak berbeda jauh dari kekasaran pada durasi 15 menit.

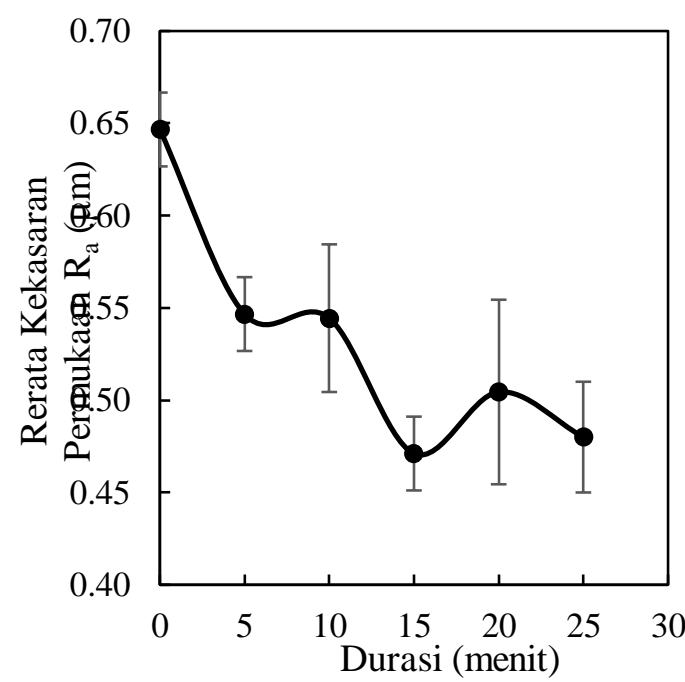

Gambar 5. Grafik kekasaran permukaan hasil drag finishing terhadap durasi finishing

Perubahan kekasaran permukaan uji juga ditunjukkan oleh morfologi permukaan spesimen uji pada Gambar 6. Pada Gambar 6(a) ditunjukkan spesimen uji awal (pra-finishing) yang masih terlihat garis-garis hasil permesinan dengan mesin bubut. Penambahan durasi drag finishing menyebabkan garis-garis itu semakin samar dan memunculkan titik-titik hasil pemakanan spesimen oleh media abrasif. Gambar 6(b) menunjukkan bahwa durasi finishing 5 menit mengakibatkan garis hasil permesinan terlihat mulai samar dan menghasilkan kekasaran 0,55 $\mu \mathrm{m}$. Kemudian dengan menambah durasi finishing mengakibatkan garis hasil permesinan berkurang dan mencapai kekasaran $\mathrm{R}_{\mathrm{a}}$ minimum $0,47 \mu \mathrm{m}$ pada durasi 15 menit (Gambar 6(d)). 
I. P. Sayuti dan Suyitno / Journal of Mechanical Design and Testing 1(2), (2019), 126-136

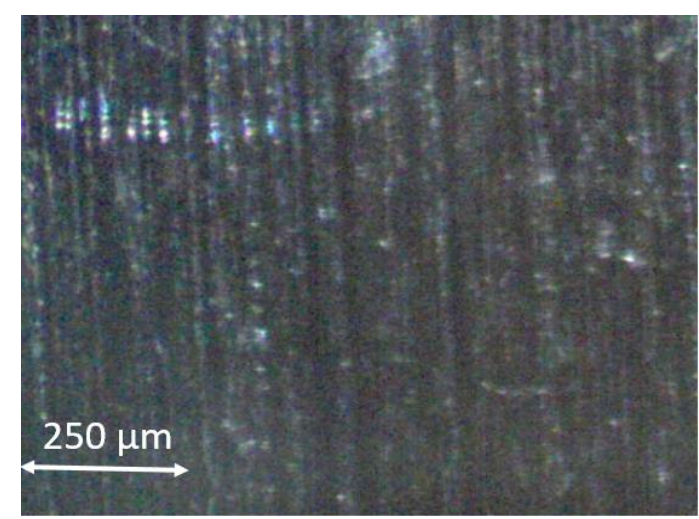

(a)

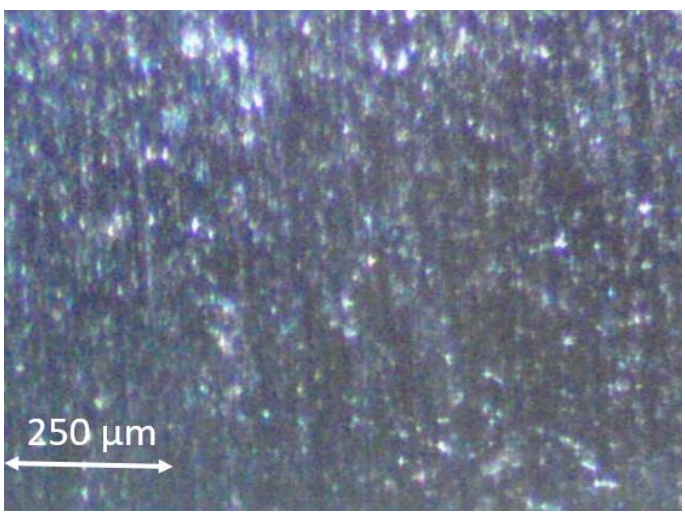

(c)

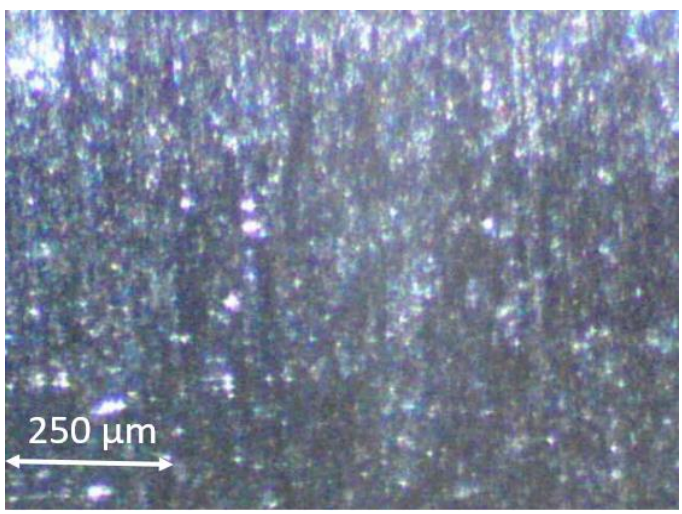

(e)

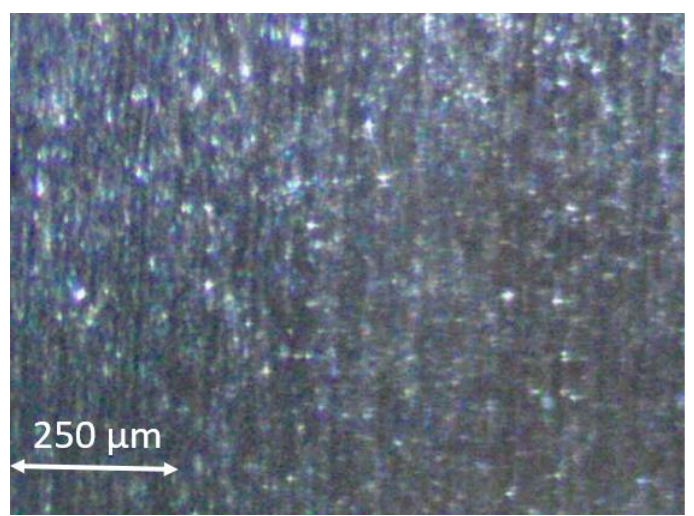

(b)

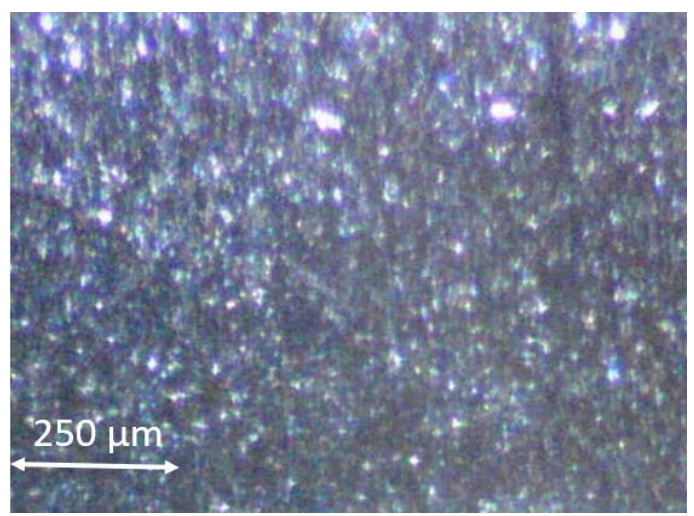

(d)

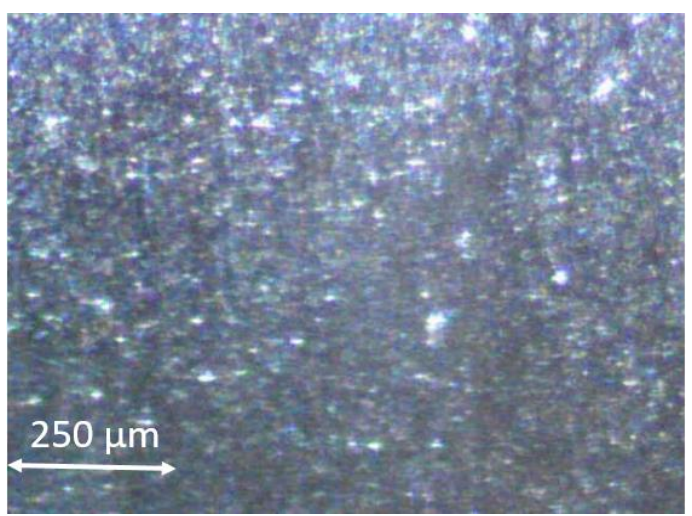

(f)

Gambar 6. Morfologi permukaan spesimen terhadap durasi finishing, (a) pra finishing, (b) 5 menit, (c) 10 menit, (d) 15 menit (e) 20 menit, (f) 25 menit

Peningkatan durasi finishing juga mempengaruhi perubahan massa spesimen uji hasil finishing seperti yang ditunjukkan pada Gambar 7. Semakin lama proses drag finishing dilakukan 
maka massa yang hilang juga semakin besar dengan nilai maksimum sebesar 0,013 g pada durasi 25 menit.

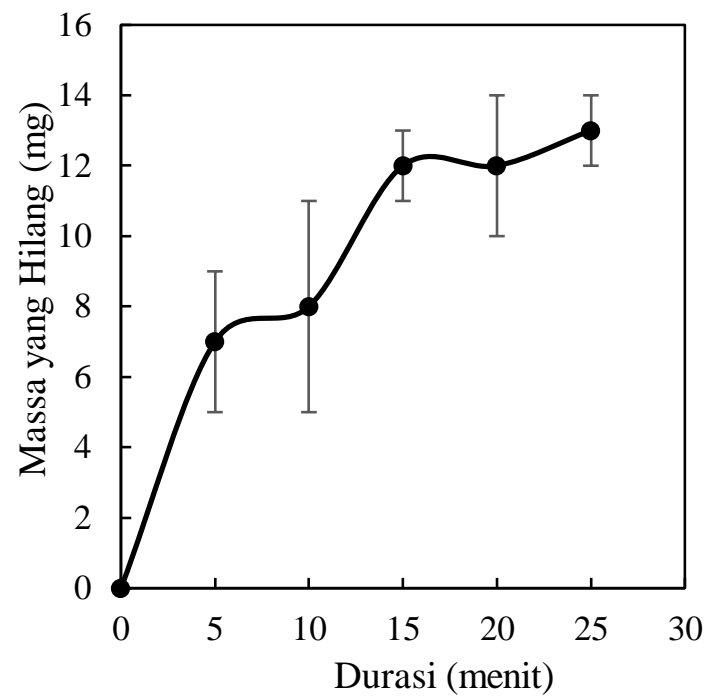

Gambar 7. Grafik perubahan massa spesimen uji pada drag finishing dengan variasi durasi finishing

Perlakuan drag finishing dengan variasi durasi finishing kemudian dihentikan karena data dan grafik dianggap telah cukup untuk merepresentasikan pengaruh durasi finishing terhadap nilai kekasaran permukaan spesimen uji. Oleh karena itu didapatkan bahwa durasi terbaik adalah 15 menit dengan tingkat kekasaran permukaan $\mathrm{R}_{\mathrm{a}}$ sebesar $0,47 \mu \mathrm{m}$.

\section{KESIMPULAN}

Proses penghalusan permukaan pada material AISI 316 L yang menjadi material untuk membuat sendi lutut artifisial dapat dilakukan dengan menggunakan proses drag finishing dengan media abrasif berupa akrilik berbentuk bola dengan diameter $4 \mathrm{~mm}$. Proses drag finishing disini menggunakan mesin milling sebagai motor penggerak spindle mengikuti kecepatan putar (rpm) yang ada pada mesin milling. Setelah dilakukan pengujian didapatkan bahwa kecepatan putar ideal untuk mendapatkan tingkat kekasaran permukaan yang optimal adalah $160 \mathrm{rpm}$ dengan durasi finishing selama 15 menit. Konfigurasi rpm dan durasi ini akan mengubah kekasaran permukaan dari $0,646 \mu \mathrm{mRa}$ menjadi $0,471 \mu \mathrm{mRa}$.

\section{DAFTAR PUSTAKA}

Arden, N., Blanco, F.J., Cooper, C., Guermazi, A., Hayashi, D., Hunter, D., Javaid, M.K., Rannou, F., Reginster, J., dan Roemer, F.W., Atlas of osteoarthritis, 1st ed, Springer Healthcare, London, 2014.

Barletta, M., Pietrobono, F., Rubino, G., dan Tagliaferri, V., Drag finishing of sensitive workpieces with fluidized abrasives, Journal of Manufacturing Processes, Volume 16, 2014, Halaman 494-502. 
Chowdury, S.K.R., Mishra, A., Pradhan, B., dan Saha, D., Wear characteristic and biocompatibility of some polymer composite acetabular cups, Wear, Volume 256, 2004, Halaman 1026-1036.

Gillespie, Mass finishing handbook, 1st ed., Industrial Press, New York, 2007.

Holzknecht, E., Everything you need to know about mechanical/mass finishing: a workshop on the role of media in mechanical surface finishing, Metal Finishing, Volume 107, 2009, Halaman 27-31.

Jaber, S.A., Ruggiero, A., Battaglia, S., dan Affatato, A., On the roughneess measurement on knee prostheses, International Journal Artificial Organs, Volume 1, 2015, Halaman 3944.

Long, M., dan Rack, H.J., Titanium alloys in total joint replacement - a metrial science perspective, Biomaterials, Volume 19, 1998, Halaman 1621-1639.

Muratoglu, O.K., Burroughs, B.R., Bragdon, C.R., Christensen, S., Lozynsky, A., dan Harris, W.H., Knee simulator wear of polyethylene tibias articulating against explanted rough femoral components, Clinical Orthopaedics and Related Research, Volume 428, 2004, Halaman 108-113.

Nine, M.J., Choudhury, D., Hee, A.C., Mootanah, R., dan Osman, N.A.A., Wear debris characterization and corresponding biological response: artificial hip and knee joints, Materials, Volume 7, 2014, Halaman 980-1016.

Rönn K, Reischl N, Gautier E, dan Jacobi M., Current surgical treatment of knee osteoarthritis, The Journal of Arthritis, Volume 2011, 2011, Halaman 1-9. 